\title{
BOH: A Unique Chemical for the Induction of Flowering in Bromeliads
}

\author{
Héctor R. Cibes and A. Santiago Nieves ${ }^{1}$
}

\section{INTRODUCTION}

The pineapple family, Bromeliaceae, is composed of stemless herbs native to tropical America whence they have been disseminated to other areas of the world. They have stiff and sometimes spiny leaves. Their flowers are borne in panicles. Perhaps the most important genus of the family is Ananas, to which the commercial pineapple varieties belong. Other members of the family are noted for the fiber obtained from their leaves. Bromelia pinguin L., or wild pineapple, a native of the West Indies, is widely used as a hedge plant and its fruit is also known to contain a proteolytic enzyme. The genus Bromelza was named after the Swedish botanist, Olaf Bromelius.

Bromeliads are becoming increasingly important as ornamental plants, both locally and in the United States. Not only the plants themselves are showy, because of their color, shape, and variegation, but also their flowers are beautiful. An important characteristic among bromeliads is that their flowers are long-lasting on the plants. Some will last, attached to the mother plant, for months without losing their beautiful appearance.

\section{FLOWER INDUCTION}

However, flowering is not uniform in this group of plants. For instance, a pineapple field may flower sporadically 10 to 15 times throughout the year, after attaining the proper age. Thus, flower-forcing during a convenient time along the growing season is imperative in commercial plantings. This is attainable through the use of suitable concentrations of either calcium carbide $\left(\mathrm{CaC}_{2}\right)$, naphthalene acetic acid (NAA), or $\beta$-hydroxyethyl hydrazine $(\mathrm{BOH})$. According to results obtained in our experimental work at the Agricultural Experiment Station, the most effective and easy to use of the three listed chemicals is $\mathrm{BOH} .^{2,3}$ Not only is flowering more uniform and prompt in $\mathrm{BOH}$-treated plants, but also the color and to some extent the quality of the fruit is improved.

1 Plant Physiologist and Research Assistant, respectively, Agricultural Experiment Station, University of Puerto Rico, Río Piedras, P.R.

2 Cibes, Héctor, R., and Gandía, Héctor, Effect of $\mathrm{BOH}$ on flowering of pineapple, Research Note, J. Agr. Univ. P.R. 46(1): 65-7, 1962.

${ }^{3}$ Unpublished data. 


\section{MATERIALS AND METHODS}

Following these findings it was considered advisable to try $\mathrm{BOH}$ on the ornamental bromeliads. Some species have never flowered in Puerto Rico

TABLE 1.-Influence of BOH upon the flowering of various bromelia species during winter in Puerto Rico

\begin{tabular}{|c|c|c|c|}
\hline Species & $\begin{array}{l}\text { BOH concentrat- } \\
\text { ion used }\end{array}$ & Data flower appeared & Days to flower \\
\hline & Percent & & Number \\
\hline Ananas bractealus & 0.06 & Jan. 4, 1964 & 50 \\
\hline Aechmea fasciata & .06 & Dec. 4,1963 & 19 \\
\hline Guzmania berteroniana & .06 & Nov. 28,1964 & 13 \\
\hline Aechmea chantinii & .06 & Jan. 4,1964 & 50 \\
\hline A. fosteriana & .06 & - & - \\
\hline A. Foster's Favorite & .06 & Dec. 8,1963 & 23 \\
\hline A. berteroniana & .06 & Nov. 28,1963 & 13 \\
\hline A. Royal Wine & .06 & Nov. 29,1963 & 14 \\
\hline A. mexicana & .06 & - & - \\
\hline A. penduliflora & .06 & Dec. 3,1063 & 18 \\
\hline A. gigantea & .06 & - & - \\
\hline Ananas comosus (variegalus) & .06 & Jan. 20, 1964 & 66 \\
\hline A. comosus (strialus) & .06 & - & - \\
\hline Billbergia venezuela & .06 & - & - \\
\hline Vriesea splendens & .06 & Dec. 2,1964 & 17 \\
\hline Aechmea wiebachii & .06 & Nov. 27,1963 & 12 \\
\hline Billbergia leptopoda & .06 & Jan. 24,1964 & 70 \\
\hline Ananas comosus (S. C.) & .06 & Dec. 13,1963 & 28 \\
\hline Tillandsia Cyanea & .03 & Nov. 24, 1963 & 9 \\
\hline Billbergia "Fantasía" & .03 & Nov. 22,1963 & 7 \\
\hline B. Hybrid & .03 & Nov. 22,1963 & 7 \\
\hline Neoregelia Carolinae & .03 & Nov. 30,1963 & 15 \\
\hline Aechmea orlandiana & .03 & Nov. 25,1963 & 10 \\
\hline Neoregelia Carolinea Tricolor & .03 & Nov. 30,1963 & 15 \\
\hline Billbergia saundersii & .03 & Dec. 4,1963 & 19 \\
\hline
\end{tabular}

and others, such as pineapples, have an erratic flowering habit, as stated before.

Thus, a collection of bromeliads was brought to the greenhouse to determine whether $\mathrm{BOH}$ would stimulate their flowering as effectively as it does in pineapples. Some 18 species were sprayed with a $\mathrm{BOH}$ solution containing 0.06 percent of the chenical, while 7 others, which were considered to be more delicate, and were treated with only half that concentration. Comparable plants were left untreated. 


\section{RESULTS}

Table 1 clearly shows the flower-inducing power of $\mathrm{BOH}$, at both concentrations, upon the various bromelia species included in the experiment. Out of 25 treated species only 5 did not flower. However, not all the plants receiving the chemical treatment flowered at the same time. The flowering time varied widely between species. In this respect it was amazing to note that the great majority of the plants, at either concentration, responded quicker than pineapple to the stimulating action of BOH. On the other hand, a few took longer to flower. It should be mentioned that pineapple plants of the Red Spanish variety flower about 30 days after treating with $\mathrm{BOH}$.

Only one species was adversely affected by the chemical, as shown by its burning effect on the leaves. This plant never bloomed.

The ornamental plant collector, as well as those in the plant and flower business, are very much interested in the early and uniform flowering of their plants, some for pleasure and others for profit. Apparently, the use of $\mathrm{BOH}$ in the culture of bromeliads will insure both objectives.

\section{SUMMARY}

$\beta$-hydroxyethyl hydrazine (BOH) was applied to 25 bromelia species in the greenhouse at two different rates according to the nature of the plants. Only five species did not flower. Flowering dates varied widely. This ranged from 7 days for the earliest to 66 days for the latest flowering species. Check plants did not flowered.

\section{RESUMEN}

Se aplicó hidrazina $\beta$-hidroxietílica (BOH) a 25 especies de bromelias cultivadas en invernadero, a dos concentraciones, según la naturaleza de las especies concernidas. De éstas, solamente 5 especies no florecieron. Entre las que florecieron, hubo una gran variación en cuanto a la época de la florecida. Esta se extendió de 7 días en el caso de la que floreció más temprano, a 66 días en el de la que más se tardó. Las plantas testigos, de la misma especie y condicion, no florecieron. 